\title{
On the Use of Computer-Aided Text Analysis in International Business Research
}

Citation for published version (APA):

Belderbos, R., Grabowska, M., Leten, B., Kelchtermans, S., \& Ugur, N. (2017). On the Use of ComputerAided Text Analysis in International Business Research. Global Strategy Journal, 7(3), 312-331. https://doi.org/10.1002/gsj.1162

Document status and date:

Published: 01/08/2017

DOI:

10.1002/gsj.1162

Document Version:

Publisher's PDF, also known as Version of record

Document license:

Taverne

Please check the document version of this publication:

- A submitted manuscript is the version of the article upon submission and before peer-review. There can be important differences between the submitted version and the official published version of record.

People interested in the research are advised to contact the author for the final version of the publication, or visit the DOI to the publisher's website.

- The final author version and the galley proof are versions of the publication after peer review.

- The final published version features the final layout of the paper including the volume, issue and page numbers.

Link to publication

\footnotetext{
General rights rights.

- You may freely distribute the URL identifying the publication in the public portal. please follow below link for the End User Agreement:

www.umlib.nl/taverne-license

Take down policy

If you believe that this document breaches copyright please contact us at:

repository@maastrichtuniversity.nl

providing details and we will investigate your claim.
}

Copyright and moral rights for the publications made accessible in the public portal are retained by the authors and/or other copyright owners and it is a condition of accessing publications that users recognise and abide by the legal requirements associated with these

- Users may download and print one copy of any publication from the public portal for the purpose of private study or research.

- You may not further distribute the material or use it for any profit-making activity or commercial gain

If the publication is distributed under the terms of Article $25 \mathrm{fa}$ of the Dutch Copyright Act, indicated by the "Taverne" license above, 


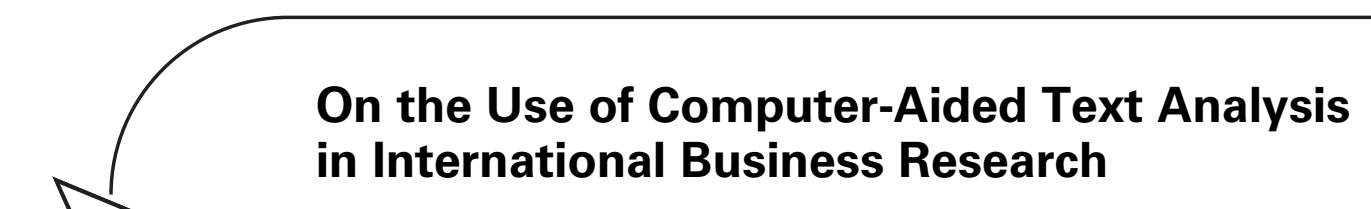

\author{
Rene Belderbos, ${ }^{1,2,3, *}$ Marcelina Grabowska, ${ }^{1}$ Bart Leten, ${ }^{1,4}$ \\ Stijn Kelchtermans, ${ }^{1,4}$ and Nazlihan Ugur ${ }^{5}$ \\ ${ }^{1} \mathrm{KU}$ Leuven, Leuven, Belgium \\ ${ }^{2}$ Maastricht University, Maastricht, The Netherlands \\ ${ }^{3}$ UNU-MERIT, Maastricht, The Netherlands \\ ${ }^{4}$ Hasselt University, Diepenbeek, Belgium \\ ${ }^{5}$ University of Amsterdam, Amsterdam, The Netherlands
}

\begin{abstract}
Research summary: This article demonstrates the potential of computer-aided text analysis (CATA) as a technique to operationalize hard-to-measure constructs in international business research, provided that a rigorous set of validity tests is applied. CATA allows researchers to perform content analyses on large textual databases by constructing indicators using deductively and inductively derived keywords. We show the critical validity steps that have to be followed to arrive at valid CATA indicators. We illustrate the CATA technique through an application to the concept of global mind-set, which has received substantial attention in the international business and strategy literature. We conclude that CATA analysis is a valuable method for international business research, but that its potential can be unleashed only with proper procedures and due attention to construct validity.
\end{abstract}

Managerial summary: With the increasing availability of large textual databases such as collections of press releases, newswire archives, and SEC filings, computeraided text analysis (CATA) creates new opportunities to analyze otherwise unobserved firm and managerial traits. CATA can be applied to a broad range of firm activities and industries across long time periods, while eschewing the low response rates typical for surveys. In this article, we demonstrate the critical validity steps that have to be followed to arrive at valid CATA indicators of firm and managerial traits, with an application to international business. As an empirical illustration, we build a keyword-based indicator of firms' global mind-sets using a large dataset of news articles. Copyright () 2017 Strategic Management Society.

With the availability of large textual databases (e.g., Factiva, LexisNexis, SEC filings), content analysis - and especially computer-aided text analysis (CATA) - is increasingly used in strategy research to infer otherwise unobserved firm and managerial traits.

Keywords: content analysis; computer-aided text analysis (CATA); global strategy; multinational firms; global mind-set *Correspondence to: Rene Belderbos, Department of Managerial Economics, Strategy \& Innovation, KU Leuven, Naamsestraat 69, 3000 Leuven, Belgium. E-mail: rene. belderbos@kuleuven.be; rene.belderbos@maastrichtuniversity.nl
Prior studies have, for instance, used CATA analysis to capture firms' endeavors in exploitation and exploration (e.g., Gatti, Volpe, \& Vagnani, 2015; Heyden, Oehmichen, Nichting, \& Volberda, 2015; Titus, House, \& Covin, 2014; Uotila, Maula, Keil, \& Zahra, 2009; Vagnani, 2015; Walrave, van Oorschot, \& Romme, 2011) and entrepreneurial orientation (e.g., Boling, Pieper, \& Covin, 2015; Engelen, Neumann, \& Schmidt, 2016; Short, Broberg, Cogliser, \& Brigham, 2010; Wolfe \& Shepherd, 2015). 
CATA allows researchers to perform content analyses on large textual databases and construct indicators from dictionaries of keywords. It has several advantages over surveys that are typically used to operationalize difficult-to-measure constructs: it is applicable to a broad range of firm activities and industries across long time periods and does not face problems related to nonresponse that are common for survey-based measures. Yet to date, there is little use of CATA analysis and textual data in international business research. The study by Heyden et al. (2015) is a partial exception and applies CATA analysis to the identification of firms' exploration orientations across institutional (country) environments. A further search of extant international business literature did not uncover other salient contributions employing CATA analysis.

In this article, we demonstrate the potential for CATA analysis in global strategy research. We show the critical procedures and validity steps that have to be followed to arrive at valid CATA indicators for a focal construct. We demonstrate how CATA indicators can be constructed on a dictionary of deductive (theory-based) and inductive (derived from the body of text) keywords and describe a structured series of tests applied to assess the validity of CATA-based measures: sampling validity, content validity, correlational and discriminant validity, predictive validity, and external validity. We illustrate the CATA technique through an application to the concept of global mind-set,

While demonstrating the broader opportunities of CATA analysis in international business research, our study also emphasizes the challenges and caveats associated with the use of CATA indicators. Text data is noisy, and indicators should be constructed on an informative body of text and should be subjected to a number of validity tests. A single dictionary of keywords furthermore is unlikely to be optimal across contexts and diverse bodies of texts. A structural approach to develop valid context-specific CATA indicators is indispensable to safely unleash the value of text data and content analysis, in particular for difficult-tomeasure constructs (Short et al., 2010).

The contribution of our article is twofold. First and foremost, it describes and illustrates how CATA analysis can be used in international business research to study dimensions of firm behavior and managerial traits that are otherwise difficult to examine across broader sets of firms and industries. Second, the message of our article presents specifics about the proper use of CATA analyses in strategy and international business research. In this regard, we contribute to the fairly nascent stream of research on the measurement and validity of constructs in strategic management (Boyd, Bergh, Ireland, \& Ketchen, 2013).

The remainder of the article is structured as follows: We next describe the procedures to arrive at valid CATA indicators. We then provide background on the empirical context and illustrate how the procedures and validity checks can be applied. Finally, we conclude and discuss the potential and challenges of CATA for international business research.

\section{Construct Development and Validation using CATA}

Content analysis is defined as a systematic, replicable approach for compressing words of a text into fewer content categories based on explicit rules of coding (Weber, 1990). In the management literature, content analysis has been performed on archival narratives such as CEO shareholder letters, annual reports, press releases, and company mission statements (Duriau, Reger, \& Pfarrer, 2007). Recent advances in computer technologies have enabled researchers to perform content analyses on large amounts of text via computer-aided text analysis (CATA) since it has a higher reliability, lower cost, and greater speed than human coding (Neuendorf, 2002). Krippendorff (2004) describes the advantages of CATA as assisting researchers in filtering, categorizing, and processing information by combining the strengths of computer reliability and expert human judgment.

Most content analyses use single words as the unit of analysis to make inferences about concepts (Tetlock, Saar-Tsechansky, \& Macskassy, 2008). The single-word approach originates from the field of psychology and has the underlying assumption that the words people use in their narrative texts are the reflection of their thoughts (Pennebaker, Mehl, \& Niederhoffer, 2003). Following this assumption, the words used in narrative texts about firms' activities (e.g., press releases, annual reports, newspaper coverage, etc.) can provide valuable information about their strategies and perceptions. When selecting keywords, two techniques can be 
used: deductive and inductive (Doucet \& Jehn, 1997; Kabanoff, Waldersee, \& Cohen, 1995). The deductive approach starts from theoretical definitions and uses critical keywords reflecting the concept of interest. In the inductive approach, the keyword list is derived from the body of text to be analyzed. Frequently used and distinctive words of interest are chosen as the relevant keywords. We recommend using a combination of deductive and inductive keyword identification to create a custom dictionary for the unique text base at hand. The empirical illustration of the CATA technique we provide later demonstrates how theory-based keywords can be augmented by keywords that have particular informational value in the text base that is analyzed.

Before empirical work can safely rely on CATA indicators, the validity of these indicators has to be demonstrated (Kerlinger \& Lee, 2000). Validity concerns the extent to which an indicator accurately represents a focal concept (Cronbach, 1971). Different techniques have been proposed in the literature to test the validity of indicators (Cronbach \& Meehl, 1955; Krippendorff, 1980, 2004; Messick, 1989, 1995). A recent study by Short et al. (2010) suggested a structured procedure for validating indicators using content analysis in organizational research. We draw on Short et al. and other prior studies on content analysis to introduce a set of validity checks for CATA indicators. This structured set of validity tests includes sampling validity, content validity, and discriminant or correlational validity, as well as predictive validity and external validity. The first three are crucial for any proper use of CATA. Passing the latter two validity tests has clear advantages, but conducting them may not always be feasible. Later, we briefly describe the nature of the tests and their objectives. Details will become clear once we apply the tests to our empirical context: the construction of a CATA-based measure of global mind-set. Figure 1 describes the validity tests and steps that have to be taken in the context of the development of the global mind-set indicator.

\section{Sampling Validity}

A first step in creating valid indicators is establishing sampling validity. Krippendorff (1980, p. 73). defines sampling validity as "the degree to which a collection of data are either statistically

Copyright (C) 2017 Strategic Management Society representative of a given universe or in some specific respect similar to another sample from the same universe so that the sample can be analysed in place of the universe of interest. In content anal$y$ sis, it is the degree to which the collection of data contains, with a minimum of bias, a maximum of relevant information about the universe, correcting particularly for the bias in their selective availability." Hence, the body of texts on which CATA analysis is performed has to be informative on the focal construct.

\section{Content Validity}

Content validity is the degree to which a measure demonstrates the behavior or phenomenon for which it is intended (Nunnally \& Bernstein, 1994). In CATA, the adequacy of the words to represent a certain construct is critical. Three procedures can be used to assess the accuracy of keywords. First, the accuracy of individual keywords is assessed by having multiple experts evaluate their appropriateness and withholding only keywords for which there is interrater agreement on their accuracy. Second, the appropriateness of individual keywords in the context of the body of text at hand should be examined via a keyword-in-context (KWIC) analysis (Krippendorff, 2004; Manning \& Schütze, 1999). KWIC analysis examines the way specific keywords are used in actual sentences in the body of text. Keywords that are frequently used in ways that are ambiguous or not directly linked to the meaning of a focal construct are removed from the dictionary of keywords. Third, the validity of the complete dictionary of keywords should be assessed by calculating the accuracy with which keywords can correctly classify articles reflecting global mind-set as such. For this purpose, article classifications based on the dictionary of CATA keywords are compared with a manual classification of articles by multiple expert raters, allowing the formal evaluation of accuracy through precision and recall, two classic criteria to assess the performance of information retrieval methods (Kent, Berry, Luehrs, \& Perry, 1955).

\section{Discriminant or Correlational Validity}

Discriminant or correlational validity measures the extent to which a construct is distinct from other constructs or similar to related constructs 


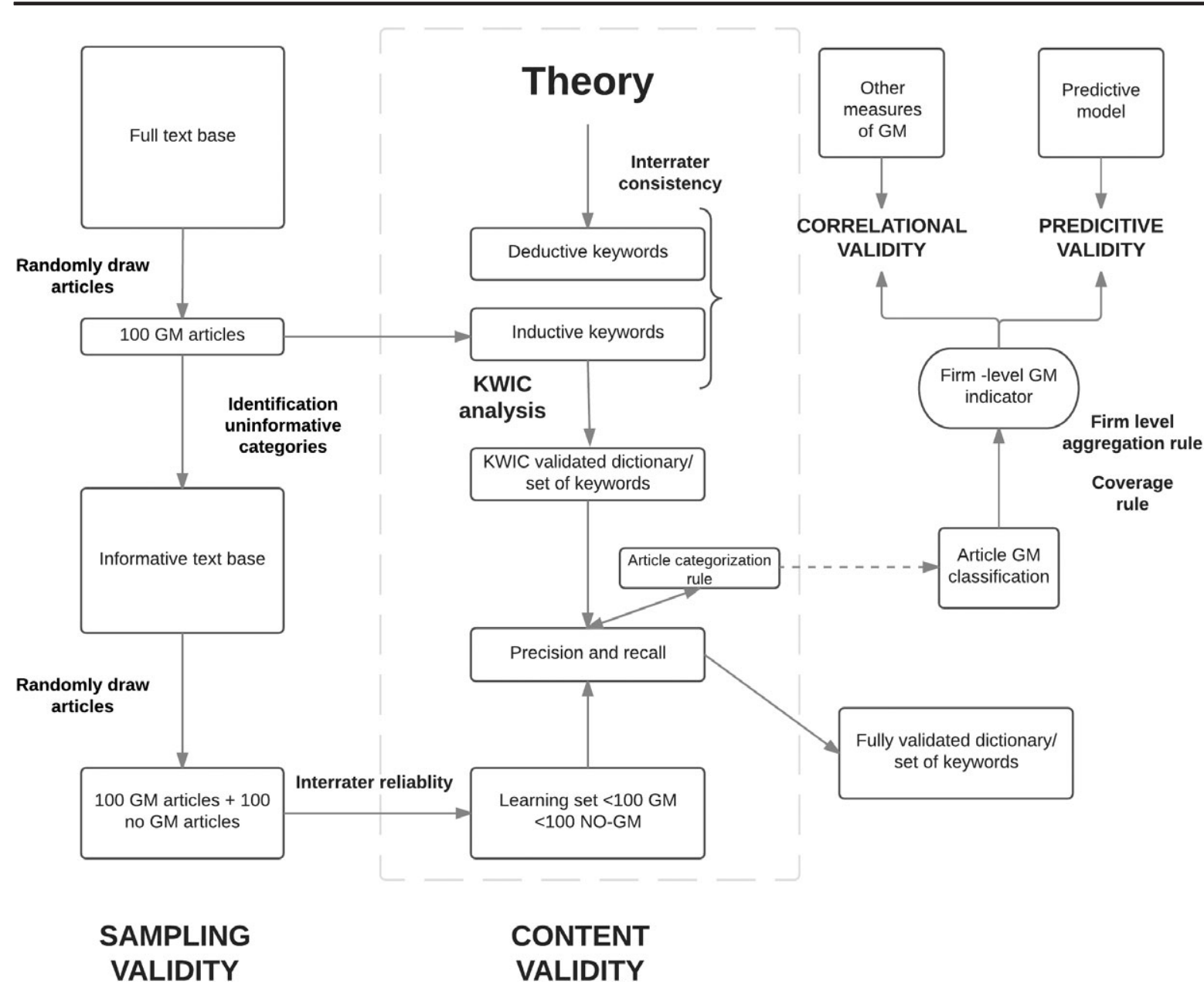

Figure 1. Validity analysis and procedures for CATA-based indicator development: an application to global mind-set.

(Campbell \& Fiske, 1959; Short et al., 2010) in ways expected from the nature of the concept. It is assessed by using a correlation analysis, including pairwise correlations and exploratory or confirmatory factor analysis (Hair et al., 1998).

\section{Predictive Validity}

Predictive validity is the degree to which an indicator behaves in a manner predicted by theory (Krippendorff, 1980). It can be assessed using regression analysis, structural equation modeling, or other accepted empirical methods associated within a particular research stream (Short et al., 2010). Such a test may not always be feasible if, for instance, there is no consensus in the literature on the behavior of the focal construct, if the
CATA-based measure is constructed to validate new theory, or if CATA-based research is exploratory.

\section{External Validity}

External validity generally refers to the ability to generalize findings across multiple settings (Cook, Campbell, \& Day, 1979). In order to evaluate the external validity of an indicator, the consistency of an indicator should be compared across multiple settings. In the context of CATA indicators, external validity would imply recalculating the indicator on a different body of text and examining the validity tests once more in this alternative setting. While creating a dictionary that can be used across contexts has obvious value for research, often the 
examination of external validity may not be practical or feasible. A lack of practicality stems from the requirement to set up a new experiment for a new body of text. Feasibility may be lacking because for different text bases, different sets of keywords may be prominent, and keywords may be associated with different types of use. KWIC analysis may give different outcomes in different contexts, and the inductive keyword approach has the aim to add relevant keywords that are specific to the body of text at hand. Hence, we advocate to replicate the keyword selection procedure and the accompanying tests for sampling-, content-, and correlational- (or discriminant) validity, rather than reapplying a specific dictionary of keywords. In the context of our empirical illustration, we do not perform an external validity test.

\section{Illustrative Empirical Context: Global Mind-set}

Global mind-set has been used to characterize the awareness of, and openness to, (international) cultural diversity of firms and the managers they employ, as well as their ability to act upon such diversity (Gupta \& Govindarajan, 2002; Kedia \& Mukherji, 1999; Levy, Beechler, Taylor, \& Boyacigiller, 2007a). ${ }^{1}$ The interest in global mind-set has been triggered by the globalization of the economy, which has placed greater demands on managers and firms to coordinate geographically dispersed activities and to deal with diverse cultures of employees, business partners, and customers (e.g., Bartlett \& Ghoshal, 1992). It has therefore been argued that multinational firms that possess a global mind-set are better equipped to deal with these complexities (Doz \& Prahalad, 1991). The intuition that this cognitive and behavioral characteristic of multinational firms may have real implications for firm strategy and performance has triggered a substantive body of research on global mind-set.

In their review of the literature on global mindset, Levy et al. (2007a) conclude that global mind-

\footnotetext{
1 A very closely related term is global orientation, which van Bulck (1979, cited in Nummela, Saarenketo, \& Puumalainen, 2004) defined as a manager's positive attitude toward international affairs and his/her ability to adjust to different environments and cultures. Throughout the article, we refer to the term global mind-set, which is more commonly used in recent contributions (Levy et al., 2007; Story \& Barbuto, 2011).
}

set is approached from two angles: a cultural perspective, rooted in the seminal work of Perlmutter (1969), who was the first to focus on the role of managerial cognition, and a strategic perspective following the work of Bartlett and Ghoshal (2002) on strategic complexity in international management. A third, integrative, perspective conceptualizes global mind-set in both cultural and strategic terms (Rhinesmith, 1992, 1996). Despite the term "mind-set," the construct as it is perceived is not restricted to managerial attitude but also includes cognitive-such as the "ability to develop and interpret" —and behavioral—such as "seeking opportunities"-aspects, as indicated in prior research (Levy, Taylor, Boyacigiller, \& Beechler, 2007b; Nummela et al., 2004).

Studies of global mind-set have been carried out at various levels of analysis, examining individuals, groups such as top management teams, or organizations. A well-known internet-based survey is the Global Mind-set Inventory (GMI), which aims to measure global mind-set at the individual manager level (Javidan, Teagarden, \& Bowen, 2010). Global mind-set at the firm or organizational level, which is also the level of analysis used in our empirical illustration, has typically been operationalized through small-scale survey evidence using diagnostic questions on organizational strategies and practices (Kobrin, 1994) or through exploratory interviews (Ananthram \& Nankervis, 2014).

Empirical work that directly measures firms' global mind-set and examines its relationship with financial performance is limited. The survey-based study by Nummela et al. (2004) analyzes the relationship between firms' global mind-set and their international performance in a sample of 123 Finnish SMEs in the IT industry. They measure global mind-set using a questionnaire of seven Likertscale items, ${ }^{2}$ which were converted into a single measure using principal component analysis. International firm performance was measured based on managers' perceptions and, alternatively, using six survey items capturing "objective" performance. The latter measure incorporated indicators such as the share of turnover from foreign markets and the percentage of foreign customers. The findings showed no convincing evidence of an association

\footnotetext{
2 The questionnaire included items like "The company's management sees the whole world as one big marketplace" and "Internationalization is the only way to achieve our growth objectives."
} 
between global mind-set and managers' subjective assessments of performance, but revealed a positive relationship with the objective indicators. In another survey-based study of 68 IT service providers in India, Raman, Chadee, Roxas, and Michailova (2013) find that global mind-set-a composite measure of six response items-positively contributes to managers' perceptions of firm performance. The reliance on survey instruments and exploratory interviews to measure the global mindset of firms has hampered progress in research since these research methods do not allow for the build-up of datasets that cover large panels of firms and long time periods. Furthermore, surveys and interviews are expensive and time consuming, often rely on self-perceived measures, and tend to suffer from low response rates and incomplete responses (Raman et al., 2013).

A number of other studies offer circumstantial evidence for a relationship between global mind-set and firm performance. For a survey of 367 Fortune 500 firms, Daily, Certo, and Dalton (2000) find that CEO international experience is positively related to corporate financial performance and that this relation is positively moderated by firm internationalization - the latter measured as a fouritem construct based on foreign sales, foreign assets, and the number and dispersion of foreign subsidiaries. Using secondary data on 245 U.S. multinationals, Carpenter, Sanders, and Gregersen (2001) confirm a positive relation between international experience of senior executives and a firm's financial performance, measured by ROA and stock market returns. They also find a positive moderation effect of firm internationalization, using a composite measure as in Daily et al., but refer to it as global strategic posture rather than firm internationalization. While the latter two studies do not explicitly employ the term global mind-set, the analyzed constructs reflect some of its cognitive and behavioral aspects.

Next, we illustrate how CATA can be used as an alternative method to develop valid indicators for the concept of global mind-set.

\section{Indicator Construction and Indicator Validity using CATA: An Application to Firms' Global Mind-set}

We employ a sample of 180 firms in technologyintensive industries, drawn from the 2004 edition of the Industrial R\&D Scoreboard. Technologyintensive industries provide greater opportunities for reaping global scale advantages and worldwide marketing and learning and represent a rich setting for global mind-set research. The industrial $R \& D$ scoreboard provides a list of the 500 most R\&D-intensive European and 500 most R\&D-intensive U.S. and Japanese firms. The sample firms are active in five different medium to high technology-intensive industries: electronics and electrical engineering, IT hardware (computers and communication equipment), pharmaceuticals and biotechnology, chemicals, and engineering and non-electrical machinery. The firms selected are the top 10-15 R\&D spending firms in their region of origin and industry.

For these firms, we conducted an extensive search in the LexisNexis newswire archive to identify articles in which the firms were mentioned, using the observation period 1995-2003. News articles reporting on the sample firms were collected at the consolidated level, i.e., all articles reporting on the parent firm as well as the consolidated (majority-owned) subsidiaries of the parent firm were taken into account. For this purpose, we used yearly lists of subsidiaries included in annual reports, yearly $10-K$ reports filed with the SEC in the U.S. and, for Japanese firms, information on foreign subsidiaries published by Toyo Keizai in the yearly Directories of Japanese Overseas Investments. The consolidation was performed on a yearly basis to allow for changes in group structures of firms due to acquisitions, mergers, de-mergers, and spin-offs. This search in the LexisNexis newswire archive produced an extensive body of 663,630 articles; but, a substantial share was uninformative on the activities of the firms, as we explain later.

We employed a combination of deductive and inductive methods to derive a dictionary of keywords capturing firms' global mind-set. We started the deductive procedure by reviewing the relevant literature and deciding on a working definition of global mind-set. We used the integrative definition of Levy et al. (2007a, p. 244), defining global mind-set as a complex cognitive structure characterized by an openness to, and articulation of, multiple cultural and strategic realities on both global and local levels and the strategic ability to mediate and integrate across this multiplicity. For the operationalization of the global mind-set concept, Levy et al. (2007b) note that the descriptors used in the 
literature encompass not only cognitive terms ("cognitive structure," "ability to interpret"...), but also existentialist ("orientation," "openness"...) and behavioral terms, with the latter capturing managerial actions and their results ("propensity to engage," "seeking opportunities"...). We follow this broad characterization of global mind-set and, therefore, do not restrict the set of keywords to terms that reflect global mind-set in a narrow sense. Combined with the verification of the context in which the keywords occur (a so-called KWIC analysis), we think this approach ensures a sufficiently broad-yet validated, so not overly broadselection of keywords that comprehensively captures the richness of the concept. The next step was to involve four expert raters in the generation of a set of keywords that align with the working definition. This resulted in a list of 26 different keywords for which there was interrater agreement.

To construct an inductive keyword list, we randomly selected (across firms and years) articles until we obtained a set of 100 news articles for which there was agreement among two expert raters that these were reporting on firms' global mind-set. This set of 100 articles was roughly evenly distributed across sectors and years and fairly representative of the sample of firms. We subsequently selected the most frequently occurring keywords in the 100 articles. This frequency-based list was reduced by removing nonrelevant (the, 1998, and, this...), generic (year, CEO, sector...), and sector-specific (cancer, semiconductor, automotive...) keywords. We selected only those keywords for which there was interrater agreement on their appropriateness for the global mind-set concept.

This inductive procedure resulted in six additional keywords. Table 1 contains the initial list of all 32 deductive and inductive keywords. These keywords were further subjected to KWIC analysis in the content validity analysis, discussed later.

\section{Sampling Validity}

The basic idea of sampling validity is that indicators are constructed on a body of text that is comprehensive and informative on the focal construct. The LexisNexis news archive includes articles from the major disseminators of news releases like Business Wire, PR Newswire Association, Information Bank Abstracts (by The New York Times),

Table 1

KWIC Results for Deductive and Inductive Keywords

\begin{tabular}{lclc}
\hline Keywords & KWIC results (\%) & Keywords & KWIC results $(\%)$ \\
\hline Deductive keywords maintained & & Deductive keywords dropped & \\
Multinational & 100 & Ethnic & 50 \\
Overseas & 97 & Opportunit & 49 \\
Worldwide & 96 & Responsiveness & 46 \\
Transnational & 96 & Ambiguity & 39 \\
Internationally & 95 & Cultur & 34 \\
Multicultur & 91 & Openness & 32 \\
Global & 91 & Cosmopolitan & 32 \\
Crosscultur & 90 & Greenfield & 32 \\
Borderless & 69 & Divers & 21 \\
Foreign & 67 & Emerging & 5 \\
& & Complex & 0 \\
& Conceptualization & 0 \\
& & Context & 0 \\
& & Integrat & 0 \\
Inductive keywords maintained & & Novel & 0 \\
Countries & & Tolerant & 0 \\
Bilateral & & Inductive keywords dropped & \\
Offshore & 95 & Venture & 47 \\
\hline
\end{tabular}


Information Access Company (Thomson Corp.), etc., as well as more specialized information brokers like Reuters Health Medical News, Intellectual Property Today, and Espicom Business Intelligence (for the pharmaceutical sector), among many others. Hence, the body of text offers a comprehensive coverage of publicly known codified information about firms' business activities and can, therefore, be considered a valid source of information on firms' global mind-set.

At the same time, in comparison with dedicated texts such as shareholder statements, news articles are heterogeneous in form and subject, and it is important to ensure that the texts used are informative on the global mind-set of our sample firms. While drawing and reading texts to arrive at the 100 articles that are deemed representative of a global mind-set, we identified two features that rendered texts unsuitable candidates for indicator development. First, when company names were observed only in the body of text but not in the headline of the article, the content of the article was rarely focused on describing activities of that focal firm. More often than not, keywords related to global mind-set described the industry or a different firm. In order to avoid misallocating keywords to firms, we restricted the text base to news articles that list the parent name or their consolidated (majority-owned) subsidiaries in the headline. Second, there were categories of articles that were clearly uninformative for indicator development on the concept of global mind-set; if left in, they would potentially bias the global mind-set indicator downward. This was the case for financial articles containing primarily numbers without commentary, such as standard reports on stock exchange developments. In particular, the first adjustment had major consequences for the body of text to be used in the analysis. Overall, the number of text articles covering the sample firms was reduced from 663,630 to 129,413 . These numbers demonstrate that one of the challenges of using unstructured and heterogeneous text archives is to arrive at a valid sample for analysis.

Once the informative text base has been established, we should confirm if each firm in the sample has sufficient coverage in the text base to build a reliable CATA indicator for that specific firmand, in the case of panel data, for each year the firm is observed. In principle, one can take the approach that if at least one article is available for the firm in a year, an indicator based on keywords occurring in the article will be reliable-provided that the indicator has been shown to be valid in the content analysis. Alternatively, one can argue that a minimum threshold of substantive coverage each year is required to reduce the noise and margin of error in the indicator due to potential misclassification. We will adopt both approaches in the correlational and predictive validity analyses and compare the results.

\section{Content Validity}

The content validity of the global mind-set indicator is assessed in three steps, of which the first two focus on the accuracy of the individual keywords used to construct the indicator. First, multiple experts evaluate the appropriateness of the keywords, resulting in a list of keywords for which there is interrater agreement on their accuracy. Second, the meaning of keywords in the specific body of text that is used to construct an indicator is examined via a KWIC analysis (Manning \& Schütze, 1999). The goal of the KWIC analysis is to examine whether keywords have an unambiguous meaning across articles (Krippendorff, 2004). For each keyword, we used NVIVO software to manually examined 50 random occurrences in our informative text base and the sentence in which the keyword was embedded. If a keyword was often used in contexts unrelated to global mind-set or the sentence containing the keyword was not indicative of global mind-set, it was categorized as an "out of context" occurrence. For example, the inductive keyword "venture" is used in a global mind-set context if it is used in the meaning of "venturing into a new country," but it is also often used in an unrelated context such as "venture capital." We calculated the shares of in-context occurrences of each keyword and required that these shares be well above $50 \%$ to include the keyword in our further indicator development. The result of this procedure is a reduced list of 13 keywords that compose the dictionary for the global mind-set indicator. The total list of keywords, their frequency of correct incontext occurrences, and their inclusion in the final dictionary are presented in Table 1. Examples of the sentences in which the keywords that passed the KWIC analysis occurred in the correct context are provided in Table A1 in the Appendix.

Second, we examined the validity of the resulting dictionary of 13 keywords by assessing the 


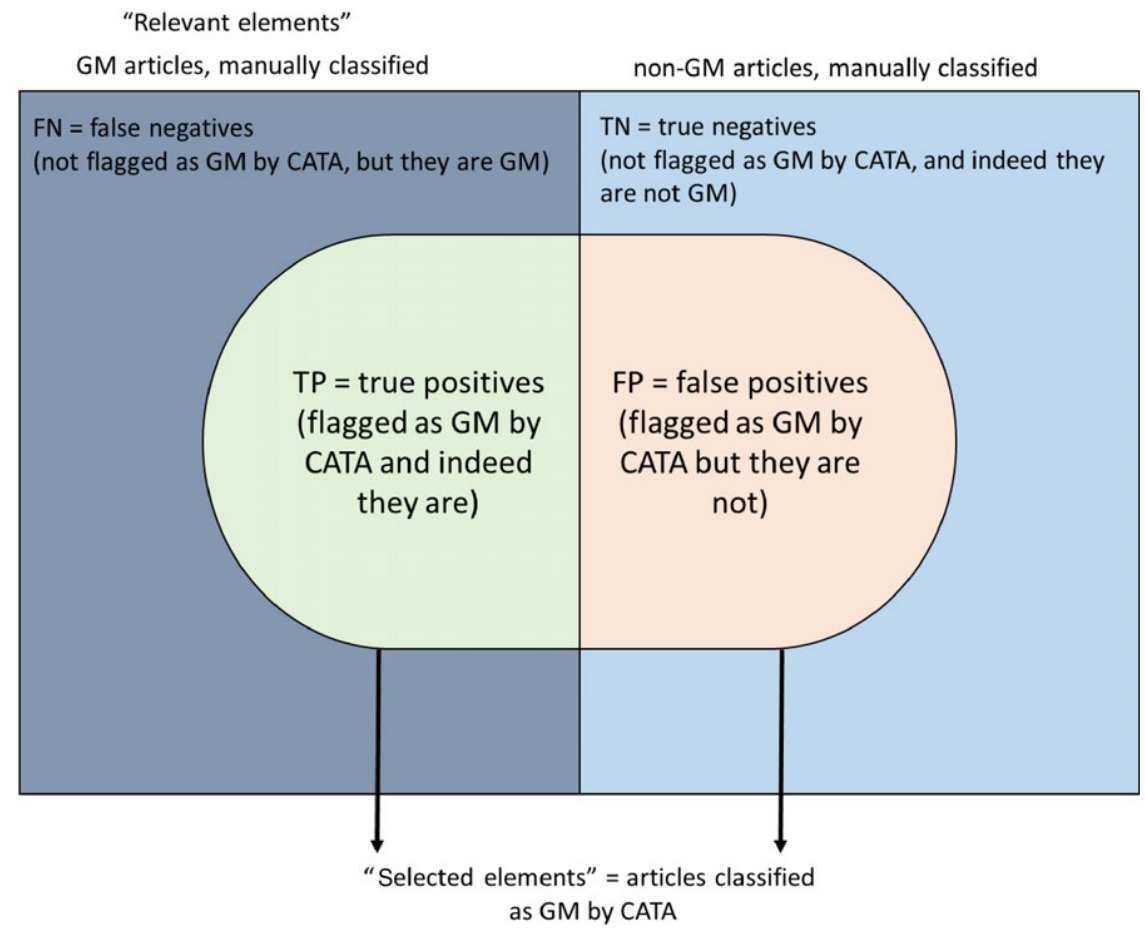

Figure 2. Measuring indicator accuracy: Precision and recall.

accuracy by which the keywords identify articles reflecting the global mind-set of firms (precision and recall). An expert rater randomly drew articles from the informative text base to arrive at two new sets of 100 articles: articles reflecting global mindset and articles not reflecting global mind-set. An independent second rater classified these articles as well, with an interrater reliability (Cohen's kappa) of $90.5 \%$. The 181 articles for which the raters had corresponding views were used for the accuracy analysis, which focuses on a comparison of the expert rater classification of articles with a classification based on the occurrence of the 13 keywords.

For the classification of articles based on keywords, we use a decision rule that is consistent with the construction of the global mind-set indicator at the firm level. There is ex ante not a specific decision rule to be preferred over others, and the choice of decision rule can be informed by the corresponding accuracy of the matching between the article classification if the decision rule is applied and the "real" classification determined on the basis of texts as classified by the two raters. The accuracy of this assignment has two dimensions: precision and recall, as illustrated in Figure 2. The precision ratio is the ratio of articles correctly classified as global mind-set articles (by the decision rule on the basis of the occurrence of keywords) over the total number of articles classified as global mind-set (incorrectly or correctly) by the decision rule: $t p /(t p+f p)$ in Figure 2. The recall ratio is the ratio of articles classified correctly as global mind-set articles by the decision rule over the total number of identified global mind-set articles (by the two raters): tp/(tp $+\mathrm{fn}$ ).

If we apply a decision rule based on one keyword (articles are classified as global mind-set articles if they contain at least one occurrence of the 13 keywords), the indicator shows a very high precision $(96 \%)$ and a substantial recall rate $(87 \%)$. Hence, the rule is rather accurate in identifying articles that are genuinely representing global mind-set, but is somewhat less powerful in retrieving all global mind-set articles. When the decision rule is made more stringent (requiring at least two keyword occurrences), the overall accuracy of the article classification improves: an increase in recall to $91 \%$ and an unchanged precision (96\%). Using three keyword occurrences slightly improves precision $(98 \%)$, but leads to a relatively strong decline in recall $(86 \%)$. We conclude that the indicators have sufficient accuracy, but that the overall accuracy is highest if the keyword-based indicator is based on a two-keyword occurrences decision rule, which we adopt in our further analysis. 


\section{Discriminant and Correlational Validity}

The aim of this validity test is to examine whether a construct is distinct from other constructs or similar to related constructs. In the case of contrasting constructs or constructs with multiple dimensions, discriminant validity tests can be performed to examine whether keywords indeed load into distinct factors. Such an examination would be at the article level. When research is dealing with a single construct, correlational validity may be an option. In the context of global mind-set, we examine to what extent the CATA-based global mind-set indicator at the firm level correlates with observed measures of firms' global strategy. Since this requires a firm-level indicator, we need to specify the construction of the CATA-based global mindset indicator at the firm level.

In general, two approaches can be adopted to construct firm-level indicators based on classified articles about the firm. A first approach calculates global mind-set as the ratio of articles classified as global mind-set articles to the total number of articles covering the firm. Hence, normalization is through the number of articles. A second approach takes into account the length of the texts and normalizes the global mind-set indicator by the total number of words found in the texts: the indicator is the total number of keywords occurring in the articles covering the firm over the total number of words summed up over the articles. In the context of heterogeneous sets of texts such as those in the LexisNexis news archive, the second approach could lead to considerable noise. Articles can include sections of irrelevant information of various length, such as series of financial numbers, discussions of the industry environment, or listings of contact persons. Although the section of the text covering firm-relevant firm behavior can be relatively small, this is not necessarily a less powerful signal on global mind-set. We take as our preferred decision rule the normalization across articles rather than across article length. ${ }^{3}$

A final issue to consider when developing a firm-year level indicator of global mind-set is the need for sufficient coverage of news articles per

\footnotetext{
3 We examined an indicator based on keyword and word counts, but found this indicator to perform substantially less well in correlational and predictive validity tests. Correlational analysis showed a low correlation with international R\&D and international sales, and predictive analysis showed no significant association with market value.
}

firm. Reliability of the indicator, in particular in a time series context, requires a certain text base covering the firm each year to identify changes properly. For instance, in case the true global mind-set value of a firm is 0.5 and there is only one article covering a firm each year, one could observe annual swings from zero to one in the indicator. Our preferred measurement at the firm-year level, therefore, requires a minimum level of articles per year, and we examined thresholds of 5 or 10 articles. For comparison, we also show results if no further restrictions are placed on the reliability of the indicator (a minimum of one article per year).

In the context of the sample firms active in technology-intensive industries and taking into account data availability, we perform correlational validity tests by correlating the indicator of global mind-set with the observed pattern of firms' international R\&D. Arguably, for technology-intensive firms, international $R \& D$ would be an expression of substantive global mind-set, as R\&D has been one of the last activities to be internationalized (Belderbos, Leten, \& Suzuki, 2013) and it is an important instrument for global opportunity seeking and exploitation (Bartlett \& Ghoshal, 1989; Kuemmerle, 1997). R\&D internationalization is measured as the percentage of a firm's patent applications of which the inventors are based in countries other than the home country of the firm. Patent data are collected from the European Patent Office, and annual changes in firms' group structure (parent firm and majority-owned subsidiaries) are taken into account. In addition, we examine the correlation with the share of international sales as another indicator of firms' international operations-albeit one that could imply a less outspoken global mind-set since international sales can result from a less locally embedded internationalization through exports.

The results show moderate but significant positive correlations of $15 \%$ and $16 \%$ between our global mind-set indicator and R\&D internationalization, if we maintain firm-year observations with a five-article and 10-article coverage, respectively. The positive and significant correlations confirm the validity of the global mind-set indicator, while the moderate degree of correlation may suggest that the global mind-set indicator captures broader aspects of global orientation. The correlations with international sales are lower at $12 \%$ (for the fivearticle coverage criterion) and $14 \%$ (for the 10article criterion), with the lower correlations likely due to the broader and deeper international 
orientation that the global mind-set indicator captures. These correlations are only marginally lower if we do not impose a criterion for a minimum firm-level article coverage: $15 \%$ (with international R\&D) and $11 \%$ (with international sales).

\section{Predictive Validity}

In our study we assess predictive validity as the degree to which empirical results are in line with the established literature suggesting that global mindset is a source of firms' long-term competitive advantage (e.g., Levy et al., 2007a). More specifically, we examine to what extent there is evidence of a positive relationship between firms' global mind-set and their (long-term) financial performance, employing multivariate analysis to control for possible confounding factors in this association.

Firms' global mind-set is a time-variant indicator operationalized as the share of informative news articles that includes at least two occurrences of global mind-set keywords identified via the CATA analysis-as discussed earlier. We take as our measure of firm performance (the natural logarithm of ) Tobin's q, which captures both short-term performance and long-term prospects (Allen, 1993; Hall, Jaffe, \& Trajtenberg, 2005; Lavie, Kang, \& Rosenkopf, 2011; Lubatkin \& Shrieves, 1986). This is important, as we may expect global mindset to have a longer-term impact on firm performance. Tobin's q is defined as the market value of the firm divided by the book value of the firm's assets (Bebchuk \& Cohen, 2005; Belderbos, Faems, Leten, \& Looy, 2010; Brown \& Caylor, 2006). Market value is defined as the sum of market capitalization (share price times the number of outstanding shares at the end of the year), preferred stock, minority interests, and total debt.

Following prior research on market valuation (e.g., Belderbos et al., 2010; Hall \& MacGarvie, 2010; Hall et al., 2005), the models of firm performance include control variables indicating the ownership of intangible assets that are likely to increase future income: $R \& D$ intensity ( $R \& D$ expenses divided by total assets) and patent intensity (patent applications divided by R\&D expenses). The models also include the one-period lagged value of log (Tobin's q). Controlling for a beginning of period level of market valuation allows the global mindset variable and the other independent variables to reflect the effects of new information reaching

Copyright (C) 2017 Strategic Management Society investors and affecting their assessments of the future income streams of the firm (Belderbos et al., 2010). In other words, we can rely on yearly contemporaneous values of firms' global mind-set to examine the effects on market valuation. The inclusion of the lagged value of Tobin's q also allows for the possibility of a gradual convergence in market valuation, as leading firms may be less able to record further market value growth. Further controls are the logarithm of firm size (total assets) and a set of sector and year dummies. The financial variables were taken from Worldscope and Compustat, as well as from corporate annual reports.

We additionally control for the role of media coverage, defined as the frequency by which firms' business activities are reported on in the press (in the sample of informative texts). Prior research indicates that it is important to control for media coverage in analyses of firm market value: initial media coverage creates liquidity and investor recognition (Barber \& Odean, 2008; Huberman \& Regev, 2001; Nguyen, 2015), while intensive coverage in the media tends to capture episodes of adverse events, referred to as the "bad news bias" in media reporting (Aman, 2013; Green, Hand, \& Penn, 2014; Tetlock, 2007). Media coverage effects may potentially confound the effects of CATA indicators such as global mind-set that are derived from the same or a similar text base.

We estimate pseudo fixed effects models by including the pre-sample mean of the dependent variable to control for time-constant firm-level fixed effects. Pseudo fixed effects models control for time-invariant unobserved heterogeneity in a similar manner as fixed or random effects models do, but have the advantage that they do not lead to biased estimates of the coefficient on the lagged dependent variable and that they do not assume strict exogeneity of the regressor (e.g., Blundell, Griffith, \& Van Reenen, 1999).

Given that we have data on the period 1995-2003 and that we employ 1 year of information on Tobin's q for the pseudo fixed effect and a year of information to include the lagged value of Tobin's q, the observations on the dependent variable cover the period 1997-2003 (7 years). Because there is no information available on Tobin's q for a number of firms, particularly in the early years (such that no presample average can be calculated), the sample for analysis is reduced to 150 firms. The panel is roughly balanced and covers 991 observations for these 150 firms that are 
Table 2

Variable Definitions

\begin{tabular}{ll}
\hline Variable & Definition \\
\hline Tobin's Q & $\begin{array}{l}\text { Firm's ratio of market value to book value (end of year) } \\
\text { Global mind-set } \\
\text { The number of press articles of the firm in a given year containing a minimum of two global mind- } \\
\text { set keywords per article, divided by the total number of press articles for the firm in the same } \\
\text { year }\end{array}$ \\
$\begin{array}{l}\text { Media coverage } \\
\text { Notal assets } \\
\text { R\&D/assets }\end{array}$ & $\begin{array}{l}\text { The firm's total assets } \\
\text { Ratio of the firm's R\&D expenditures to its total assets } \\
\text { Patents/ R\&D }\end{array}$ \\
\hline
\end{tabular}

covered by at least one article in the informative text base from LexisNexis. If we drop firm-year observations if the article coverage for the firm in that year is smaller than 5 or 10 , the number of firms in the sample for estimation is further reduced from 150 to 145 and 133 and the number of observations from 991 to 876 and 761, respectively.

Table 2 provides an overview of the variable definitions, Table 3 shows descriptive statistics and correlations between the variables (for the fivekeyword case with 876 observations), and Table 4 reports the empirical results. Model 1 in Table 4 includes only the control variables. In Model 2, we include the global mind-set indicator. Both models are estimated using the restriction of minimum five articles per firm and year. Models 3 and 4 follow the same setup, but are based on a minimum of 10 articles per firm and year. Models 5 and 6 are estimated on the sample obtained if no minimum coverage criterion is applied.

In all models, the coefficient on the lagged dependent variable is positive but smaller than 1 , suggesting that leading market value firms maintain part of their leadership in the subsequent period. R\&D intensity and patent productivity affect market valuation positively, as expected, while media coverage also has a significant positive effect. Model 2 shows a positive and significant association between global mind-set and market value. ${ }^{4}$ In Model 4, which imposes a more stringent coverage criterion of at least 10 articles per firm per year, the effect of global mind-set remains significant, with the estimated coefficient very similar to the coefficient in Model 2. Conversely, if we do not impose any threshold on the number of articles

\footnotetext{
4 Adding the square term of global mind-set to gauge if the relationship is characterized by declining marginal effects (Bouquet, 2005) did not reveal any significant results.
}

covering a firm, the coefficient on global mind-set becomes statistically insignificant (Model 6). In terms of the implied magnitude of the relationship between global mind-set and market valuation, the coefficient in Model 2 suggests that a 1 standard deviation increase in the global mind-set indicator increases Tobin's q by close to $3 \%$.

\section{Sensitivity Analysis}

We conducted a number of additional analyses to explore the robustness of the CATA indicator of firms' global mind-set. First, we tested the sensitivity of the results to the article categorization rule. More specifically, while the main results reported in Table 4 required a minimum of two matching keywords to classify an article as reflecting a firm's global mind-set, we also examined correlational and predictive validity using the one-keyword and three-keyword classification rules. The correlations of the global mind-set indicator with the two alternative measures of global strategy using the onekeyword rule are $14 \%$ for R\&D internationalization and $8 \%$ for international sales. These correlations are lower than the correlations for our focal twokeyword rule indicator (15 and 12\%, respectively). For the three-keyword indicator, the percentages are essentially unchanged compared with the twokeyword indicator. We also compared the results of the predictive validity tests for alternative article categorization rules, which are relegated to the Appendix (Table A2). The three alternative indicators have estimated coefficients that are similar in magnitude, but the coefficient on the three-keyword indicator is only marginally statistically significant. Overall, these results appear to confirm our preference for the two-keyword indicator based on the precision and recall in the content validity analysis. 
Table 3

Descriptive Statistics and Correlations

\begin{tabular}{lcccccccccc}
\hline \multicolumn{1}{c}{ Variable } & & Mean & S.D. & Min & Max & \multicolumn{1}{c}{$(1)$} & $(2)$ & (3) & (4) & (5) \\
\hline Log Tobin's q & $(1)$ & 0.32 & 0.70 & -1.66 & 2.78 & & & & & \\
Global mind-set & $(2)$ & 0.31 & 0.18 & 0 & 1 & $0.17^{* * *}$ & & & & \\
Log media & $(3)$ & 3.90 & 1.40 & 1.61 & 7.29 & $0.26^{* * *}$ & 0.01 & & & \\
$\quad$ coverage & & & & & & & & & & \\
Log total assets & $(4)$ & 15.80 & 1.15 & 11.76 & 18.58 & $-0.11^{* * *}$ & -0.05 & $0.58^{* * *}$ & & \\
R\&D/assets & $(5)$ & 0.06 & 0.04 & 0 & 0.35 & $0.45^{* * *}$ & 0.03 & $0.38^{* * *}$ & $-0.16^{* * *}$ & \\
Patents/R\&D & $(6)$ & 0 & 0 & 0 & 0 & $-0.12^{* * *}$ & -0.02 & $-0.15^{* * *}$ & -0.03 & $-0.37^{* * * *}$ \\
\hline
\end{tabular}

Note. Descriptive statistics and correlations for 876 observations, using a min. 5-article criterion for global mind-set.

Table 4

Global Mind-set and Firm's Market Value: Pseudo Fixed Effects Model Results

\begin{tabular}{|c|c|c|c|c|c|c|}
\hline \multirow[b]{2}{*}{ Variable } & Model 1 & Model 2 & Model 3 & Model 4 & Model 5 & Model 6 \\
\hline & \multicolumn{2}{|c|}{$\begin{array}{l}\text { Minimum } 5 \text { articles per } \\
\text { firm per year }\end{array}$} & \multicolumn{2}{|c|}{$\begin{array}{l}\text { Minimum } 10 \text { articles per } \\
\text { firm per year }\end{array}$} & \multicolumn{2}{|c|}{$\begin{array}{l}\text { Minimum } 1 \text { article per firm } \\
\text { per year }\end{array}$} \\
\hline Global mind-set & & $\begin{array}{l}0.1296^{* *} \\
(0.0586)\end{array}$ & & $\begin{array}{r}0.1241^{*} \\
(0.0636)\end{array}$ & & $\begin{array}{c}0.0455 \\
(0.0479)\end{array}$ \\
\hline Log Tobin's q $\mathrm{q}_{\mathrm{t}-1}$ & $\begin{array}{l}0.7470^{* * *} \\
(0.0211)\end{array}$ & $\begin{array}{l}0.7375^{* * *} \\
(0.0213)\end{array}$ & $\begin{array}{l}0.7506^{* * * *} \\
(0.0200)\end{array}$ & $\begin{array}{l}0.7418^{* * *} \\
(0.0212)\end{array}$ & $\begin{array}{l}0.7625^{* * * *} \\
(0.0195)\end{array}$ & $\begin{array}{l}0.7589^{* * * *} \\
(0.0197)\end{array}$ \\
\hline Log media coverage & $\begin{array}{l}0.0240^{* * *} \\
(0.0098)\end{array}$ & $\begin{array}{l}0.0240^{* *} \\
(0.0097)\end{array}$ & $\begin{array}{c}0.0152 \\
(0.0116)\end{array}$ & $\begin{array}{c}0.0159 \\
(0.0117)\end{array}$ & $\begin{array}{l}0.0178^{* *} \\
(0.0085)\end{array}$ & $\begin{array}{l}0.0174^{* * *} \\
(0.0086)\end{array}$ \\
\hline Log total assets & $\begin{array}{r}-0.0242^{*} \\
(0.0135)\end{array}$ & $\begin{array}{l}-0.0228^{*} \\
(0.0131)\end{array}$ & $\begin{array}{l}-0.0188 \\
(0.0142)\end{array}$ & $\begin{array}{c}-0.0179 \\
(0.0139)\end{array}$ & $\begin{array}{l}-0.0181 \\
(0.0130)\end{array}$ & $\begin{array}{l}-0.0170 \\
(0.0130)\end{array}$ \\
\hline R\&D/assets & $\begin{array}{l}1.0828^{* * *} \\
(0.2660)\end{array}$ & $\begin{array}{l}1.1188^{* * *} \\
(0.2689)\end{array}$ & $\begin{array}{l}1.1276^{* * *} \\
(0.2753)\end{array}$ & $\begin{array}{l}1.1441^{* * *} \\
(0.2803)\end{array}$ & $\begin{array}{l}1.1092^{* * *} \\
(0.2569)\end{array}$ & $\begin{array}{l}1.1266^{* * * *} \\
(0.2590)\end{array}$ \\
\hline Patent/R\&D & $\begin{array}{l}78.7299^{* *} \\
(37.2037)\end{array}$ & $\begin{array}{l}81.4408^{* *} \\
(37.8796)\end{array}$ & $\begin{array}{l}63.8216 \\
(39.3981)\end{array}$ & $\begin{array}{c}60.7724 \\
(39.0178)\end{array}$ & $\begin{array}{l}87.8508^{* * *} \\
(33.9826)\end{array}$ & $\begin{array}{l}90.4256^{* * * *} \\
(34.0814)\end{array}$ \\
\hline $\begin{array}{l}\text { Pre-sample average (pseudo } \\
\text { fixed effect) }\end{array}$ & $\begin{array}{l}0.1370^{* * *} \\
(0.0263)\end{array}$ & $\begin{array}{l}0.1416^{* * *} \\
(0.0257)\end{array}$ & $\begin{array}{l}0.1482^{* * *} \\
(0.0221)\end{array}$ & $\begin{array}{l}0.1511^{* * * *} \\
(0.0221)\end{array}$ & $\begin{array}{l}0.1300^{* * * *} \\
(0.0255)\end{array}$ & $\begin{array}{l}0.1323^{* * * *} \\
(0.0252)\end{array}$ \\
\hline Constant & $\begin{array}{c}0.3101 \\
(0.2008)\end{array}$ & $\begin{array}{l}0.2422 \\
(0.1950)\end{array}$ & $\begin{array}{c}0.2727 \\
(0.2065)\end{array}$ & $\begin{array}{c}0.2133 \\
(0.2007)\end{array}$ & $\begin{array}{c}0.2239 \\
(0.1945)\end{array}$ & $\begin{array}{c}0.1920 \\
(0.1947)\end{array}$ \\
\hline $\mathrm{N}$ observations & 876 & 876 & 761 & 761 & 991 & 991 \\
\hline N Firms & 145 & 145 & 133 & 133 & 150 & 150 \\
\hline Adjusted $\mathrm{R}^{2}$ & 0.82 & 0.82 & 0.83 & 0.83 & 0.82 & 0.82 \\
\hline F-test & 514.51 & 469.96 & 530.82 & 489.23 & 544.74 & 509.82 \\
\hline
\end{tabular}

Note. Standard errors in parentheses.

${ }^{*} p<.1,{ }^{* * *} p<.05,{ }^{* * *} p<.01$.

Second, we constructed an alternative global mind-set indicator that is based only on deductive keywords and compared it with our focal indicator that also incorporates the inductive keywords. The expectation is that an approach that draws on theory and that takes into account the specificities of the text base at hand will yield a more valid indicator. If we limit the indicator to deductive keywords, precision declines marginally to $95 \%$ (compared to $96 \%$ for our focal indicator), while recall falls by a relatively larger margin to $81 \%$ (compared to $91 \%$ for the focal indictor). The deductive keywordsonly indicator is also more weakly correlated with international $\mathrm{R} \& \mathrm{D}(10$ vs. $15 \%)$ and with international sales ( 8 vs. $12 \%) .^{5}$ In contrast, the results on predictive validity for the deductive-only indicator

\footnotetext{
${ }^{5}$ Correlations and predictive validity results are for the sample of 876 observations, i.e., applying the coverage criterion of a minimum of five articles per firm and year.
} 
remain similar, showing a significant association with firm performance, with a marginally higher coefficient. The relatively similar results in this case are likely due to the fact that the inductive analysis of this particular text base generated only three additional keywords. Perhaps the results also indicate relatively lesser power of the predictive validity model to distinguish between more or less accurately measured constructs.

We conclude that our illustrative analysis contributes to the literature on global mind-set by demonstrating how an indicator of this construct can be developed from a CATA-based analysis of a large body of unstructured texts. Furthermore, we show that global mind-set has a robust and significant association with firm financial performance in a multivariate model, controlling for potential confounding influences. We encourage future research on global mind-set drawing on CATA indicators to explore the role of moderators and different contexts expected to strengthen or weaken the relationship between firms' global mind-set and their financial performance.

\section{Discussion and Conclusion}

Our study demonstrated the correct use and potential value of CATA indicators and analyses in global strategy research. We showed the critical procedures and validity steps that have to be followed to arrive at valid CATA-based indicators for focal constructs, most notably an assessment of sampling validity and the related selection of informative texts, a detailed content validity, and a correlation or discriminant validity analysis. Two additional validity tests that are not always feasible, but which have clear advantages, are predictive validity and external validity. Our study adds to the scarce literature emphasizing the importance of sound methodologies and construct validity in management research, which has warned against imprecise and incorrect measurement of constructs (e.g., Boyd et al., 2013; Ketchen, Boyd, \& Bergh, 2008). Credible research contributing to cumulative knowledge building requires that measures are reliable, effectively capturing the constructs under study (Ketchen et al., 2008).

Our illustration suggests that CATA indicator development can open up new opportunities for international business research, but at the same time poses substantial challenges. While we demonstrate how to address these challenges through a thorough validity analysis, our analysis also highlights the discretion a researcher has to exercise to obtain a valid CATA indicator, such as decisions on the body of informative texts, the decision rule to classify articles on the basis of keywords, the level of satisfactory accuracy of the indicator, and the aggregation of an article-based indicator to the firm level. We recommend that research using CATA-based indicators document these decisions clearly-which has not been established practice in the extant literature-to clarify how these challenges were approached and to allow for replication.

We emphasize that our study does not and cannot generate a universal set of keywords to measure global mind-set that is valid for each and every context. Hence, we abstracted from examining the external validity of our dictionary and the keywordbased indicator. What we recommend for future research that develops CATA indicators is to follow the prescribed structured set of validity tests in order to arrive at valid and better interpretable indicators specific to the research context. We see this as a prerequisite to exploit the full advantages of text-based indicators- i.e., their accessibility, broad availability across sectors, firms, and years, and their potential application to a variety of strategic management-and international business-related questions. Our results indicate that a set of keywords derived from theory can be improved upon through an inductive approach that yields additional keywords appearing frequently and distinctively in the collection of texts and by a careful KWIC analysis that may lead to the elimination of keywords from a given dictionary if the keywords occur in an appropriate context in the text body at hand.

Our analysis also shows that accounting for idiosyncrasies of the textual data sources is crucial for valid construct measurement and hypothesis testing. Broadly speaking, we can identify three approaches in the literature utilizing text data to deal with the challenge. First, researchers can categorize all articles manually. This has the advantage that it bypasses issues of measurement error in CATA analysis, but it is generally applicable only to settings with a limited number of texts. Second, researchers can limit the sampling to a homogenous group of texts such as annual statements to shareholders in annual reports (e.g., Engelen et al., 2016; Vagnani, 2015). This will reduce measurement errors, but it limits the perspective on firm behavior and leaves a wealth of information untouched. Third, researchers can apply CATA analysis to large, unstructured, and heterogeneous text databases such as news archives. This approach uses the 
richest information on firms, but it is most prone to measurement error and potential invalidity of applying identical sets of keywords across contexts. Here we propose that a series of structured validity tests for measures using a combination of deductive and inductive keywords is a promising approach to preserve the richness of the data while limiting measurement error.

Finally, the empirical example can illustrate how the underlying measurement model of a construct influences the approach to testing the validity of the indicator. In particular, the review of the literature on global mind-set highlighted that it is a multidimensional construct, encompassing both cultural and cognitive (or strategic) aspects. By starting from theory to generate keywords, this inherent multidimensionality of the construct is acknowledged and captured through the set of keywords, which jointly describe the underlying global mind-set construct. In other words, underlying our empirical approach is a reflective measurement model of global mind-set, with each keyword "reflecting" the construct. Given that each keyword partially captures the construct and, therefore, the whole set contains some redundancy, reflective measures tend to be quite resilient against measurement error. This is a distinct advantage when working with large volumes of unstructured and "noisy" data, such as that typically used in CATA analysis. Furthermore, some of the keywords are ambivalent, as they relate to both dimensions-such as "worldwide" and "borderless"-rather than only one. The presence of ambivalent keywords does not align with a purely formative measurement model in which measures describe different dimensions of a construct, display minimal overlap, and are less resilient to measurement error (Edwards, 2011). In other words, while some keywords map to a single dimension (e.g., multicultural), others are not subsumed clearly in only one of the constituent dimensions of global mind-set. A formative measurement model would discard such ambivalent keywords, reducing the accuracy of the indicator.

More fundamentally, and going back to our overarching objective of providing advice for ensuring construct validity in CATA analysis, the measurement model has implications for the validity tests of the indicator. In particular, the presence of ambivalent keywords explains why we did not engage in testing correlations among keywords, as this principle from classical measurement theory applies only to keywords that relate to a single dimension of the construct. Generalizing beyond the empirical illustration in this article, the advice of Bollen and Lennox (1991)—advocating that researchers should explicitly reflect on the measurement model that relates indicators and constructsapplies unabated in the development of CATA indicators, as it affects the validity tests that should be taken into consideration.

\section{Limitations}

Venturing into new data sources and developing novel techniques and indicators invariably spawns ideas for further robustness checks and refinement. Here, we highlight what we believe are the main caveats of indicator development described in our study and how further research might address them.

First, a key data limitation is that we do not observe whether the source of the article can be traced back to the firm or whether it is produced by external observers such as journalists or analysts. This distinction is of interest since there may be structural differences in their objectivity or, more generally, the way of reporting about firm activities (Morris, 1994).

Second, we relied on a database of news articles to illustrate the use of CATA analysis. While the global mind-set construct encompasses both cognitive and behavioral elements, news articles are probably better suited to identify behavioral than cognitive elements. Thus, the nature of the text base plays an important role in the ability to fully capture the different dimensions of the global mind-set concept. News articles are also a better source of information on firms than on the individuals employed by these firms. In this regard, the text base also affects the level of analysis: in our empirical illustration, we do not explicitly differentiate between the firm, its subsidiaries, or its managers. Rather, we take a consolidated approach, measuring global mind-set at the aggregate firm level.

Third, while we followed the dominant approach for content analysis in the management literature by counting single keywords (Bligh, Kohles, \& Meindl, 2004; Heyden et al., 2015; Lyon, Lumpkin, \& Dess, 2000; Vagnani, 2015), the text analysis literature offers several ways for refinement. For example, the trade-off between precision and recall in automatic text classification has led to the use of weights that contain both precision- and recallenhancing components, such as term frequencies and inverse document frequencies (Liu, Loh, \& Sun, 2009; Salton \& Buckley, 1988). 
Finally, our procedure could be strengthened by checking more explicitly for synonyms in the construction of the keyword dictionary (e.g., Heyden et al., 2015), to the extent that the inductive method does not already accommodate them automatically. While we applied a KWIC analysis, the search for relevant contexts could be extended by using word concordance software to retrieve all keyword contexts that occur in the data. Alternatively, the contexts for a given keyword could be drawn from an existing collection, as done in corpus linguistics, which studies real-life language use on the basis of a text corpus (Manning, 2003; Pollach, 2012).

\section{Conclusion}

The overall message of our analysis consists of both an endorsement and a warning for the use of CATA indicators in international business research. An endorsement because-as recent research has shown-the data sources for using content analysis are commonly available, easily accessible, and sufficiently rich in content. This allows for the construction of indicators that are applicable across sectors and time, a feature existing indicators typically cannot provide. However, the use of CATA indicators is also associated with a number of caveats. Text data is noisy, and indicators should be constructed on an informative body of text. If anything, our analysis demonstrates that a structural approach to ensure the validity of CATA indicators is indispensable to safely unleash the value of text data and content analysis. This message extends beyond the illustration of the application of global mind-set toward the proper use of CATA analyses in management and international business research. In this regard, we respond to the call by Boyd et al. (2013) to give more attention to the measurement and validity of constructs in strategic management. We believe that a considerate approach in building robust CATA indicators such as the one described in this article could constitute a major impetus for future international business research.

\section{Acknowledgements}

The authors wish to thank Torben Pedersen and Ram Mudambi for their constructive comments on an earlier draft and Shinya Suzuki for providing the international sales data. This research benefitted from financial support by the Research Foundation - Flanders (FWO grant G073013N) and the KU Leuven Research Council (Grant OT-3H140271).

\section{References}

Allen, F. (1993). Strategic management and financial markets. Strategic Management Journal, 14(S2), 11-22.

Aman, H. (2013). An analysis of the impact of media coverage on stock price crashes and jumps: Evidence from Japan. Pacific-Basin Finance Journal, 24, 22-38.

Ananthram, S., \& Nankervis, A. R. (2014). Outcomes and benefits of a managerial global mind-set: An exploratory study with senior executives in North America and India. Thunderbird International Business Review, 56(2), 193-209.

Barber, B. M., \& Odean, T. (2008). All that glitters: The effect of attention and news on the buying behavior of individual and institutional investors. Review of Financial Studies, 21(2), 785-818.

Bartlett, C. A., \& Ghoshal, S. (1989). Managing across boarders: The transnational solution. Boston, MA: Harvard Business School Press.

Bartlett, C. A., \& Ghoshal, S. (1992). What is a global manager? Harvard Business Review, 70(5), 124-132.

Bartlett, C. A., \& Ghoshal, S. (2002). Managing across borders: The transnational solution. Boston, MA: Harvard Business School Press.

Bebchuk, L. A., \& Cohen, A. (2005). The costs of entrenched boards. Journal of Financial Economics, 78(2), 409-433.

Belderbos, R., Faems, D., Leten, B., \& Looy, B. V. (2010). Technological activities and their impact on the financial performance of the firm: Exploitation and exploration within and between firms. Journal of Product Innovation Management, 27(6), 869-882.

Belderbos, R., Leten, B., \& Suzuki, S. (2013). How global is $R \& D$ ? Determinants of the home country bias in R\&D. Journal of International Business Studies, 44(8), 765-786.

Bligh, M. C., Kohles, J. C., \& Meindl, J. R. (2004). Charisma under crisis: Presidential leadership, rhetoric, and media responses before and after the September 11th terrorist attacks. Leadership Quarterly, 15(2), 211-239.

Blundell, R., Griffith, R., \& Van Reenen, J. (1999). Market share, market value and innovation in a panel of British manufacturing firms. Review of Economic Studies, 66(3), 529-554.

Boling, J. R., Pieper, T. M., \& Covin, J. G. (2015). CEO tenure and entrepreneurial orientation within family and non family firms. Entrepreneurship Theory and Practice, 40(4), 891-913. 
Bollen, K., \& Lennox, R. (1991). Conventional wisdom on measurement: A structural equation perspective. Psychological Bulletin, 110(2), 305.

Bouquet, C. A. (2005). Building global mindsets: An attention-based perspective. New York, NY: Palgrave Macmillan.

Boyd, B. K., Bergh, D. D., Ireland, R. D., \& Ketchen Jr., D. J. (2013). Constructs in strategic management. Organizational Research Methods, 16(1), 3-14.

Brown, L. D., \& Caylor, M. L. (2006). Corporate governance and firm valuation. Journal of Accounting and Public Policy, 25(4), 409-434.

Campbell, D. T., \& Fiske, D. W. (1959). Convergent and discriminant validation by the multitrait-multimethod matrix. Psychological Bulletin, 56(2), 81.

Carpenter, M. A., Sanders, W. G., \& Gregersen, H. B. (2001). Bundling human capital with organizational context: The impact of international assignment experience on multinational firm performance and CEO pay. Academy of management journal, 44(3), 493-511.

Cook, T. D., Campbell, D. T., \& Day, A. (1979). Quasiexperimentation: Design \& analysis issues for field settings. Boston, MA: Houghton Mifflin.

Cronbach, L. J., \& Meehl, P. E. (1955). Construct validity in psychological tests. Psychological Bulletin, 52(4), 281.

Cronbach, L. J. (1971). Test validation. R. L. Thorndike (Ed.), Educational measurement (2nd ed., pp. 443-507). Washington DC: American Council on Education.

Daily, C. M., Certo, S. T., \& Dalton, D. R. (2000). International experience in the executive suite: The path to prosperity? Strategic Management Journal, 21(4), 515-523.

Doucet, L., \& Jehn, K. A. (1997). Analyzing harsh words in a sensitive setting: American expatriates in communist China. Journal of Organizational Behavior, 18, 559-582.

Doz, Y. L., \& Prahalad, C. K. (1991). Managing DMNCs: A search for a new paradigm. Strategic Management Journal, 12(S1), 145-164.

Duriau, V. J., Reger, R. K., \& Pfarrer, M. D. (2007). A content analysis of the content analysis literature in organization studies: Research themes, data sources, and methodological refinements. Organizational Research Methods, 10(1), 5-34.

Edwards, J. R. (2011). The fallacy of formative measurement Organizational Research Methods, 14(2), 370-388.

Engelen, A., Neumann, C., \& Schmidt, S. (2016). Should entrepreneurially oriented firms have narcissistic CEOs? Journal of Management, 42(3), 698-721.

Gatti, C., Volpe, L., \& Vagnani, G. (2015). Interdependence among productive activities: Implications for exploration and exploitation. Journal of Business Research, 68(3), 711-722.
Green, J., Hand, J. R., \& Penn, M. W. (2014). Business press coverage and the market pricing of good and bad news (Working Paper 1780162), Social Science Research Network. [WWW document]. Retrieved from https://papers.ssrn.com/sol3/papers.cfm?abstract_id= 1780162SSRN

Gupta, A. K., \& Govindarajan, V. (2002). Cultivating a global mindset. Academy of Management Executive, 16(1), 116-126.

Hall, B. H., Jaffe, A., \& Trajtenberg, M. (2005). Market value and patent citations. RAND Journal of Economics, 36(1), 16-38.

Hall, B. H., \& MacGarvie, M. (2010). The private value of software patents. Research Policy, 39(7), 994-1009.

Hair, J. F., Black, W. C., Babin, B. J., Anderson, R. E., \& Tatham, R. L. (1998). Multivariate data analysis (6th ed.), Upper Saddle River, NJ: Prentice hall.

Heyden, M. L., Oehmichen, J., Nichting, S., \& Volberda, H. W. (2015). Board background heterogeneity and exploration-exploitation: The role of the institutionally adopted board model. Global Strategy Journal, 5(2), 154-176.

Huberman, G., \& Regev, T. (2001). Contagious speculation and a cure for cancer: A nonevent that made stock prices soar. Journal of Finance, 56(1), 387-396.

Javidan, M., Teagarden, M., \& Bowen, D. (2010). Making it overseas. Harvard Business Review, 88(4), 109-113.

Kabanoff, B., Waldersee, R., \& Cohen, M. (1995). Espoused values and organizational change themes. Academy of Management Journal, 38(4), 1075-1104.

Kedia, B. L., \& Mukherji, A. (1999). Global managers: Developing a mindset for global competitiveness. Journal of World Business, 34(3), 230-251.

Kent, A., Berry, M. M., Luehrs, F. U., \& Perry, J. W. (1955). Machine literature searching VIII. Operational criteria for designing information retrieval systems. Journal of the Association for Information Science and Technology, 6(2), 93-101.

Kerlinger, F. N., \& Lee, H. B. (2000). Foundations of behavioral research (4th ed.). Orlando, FL: Thomson Learning.

Ketchen Jr., D. J., Boyd, B. K., \& Bergh, D. D. (2008). Research methodology in strategic management: Past accomplishments and future challenges. Organizational Research Methods, 11(4), 643-658.

Kobrin, S. J. (1994). Is there a relationship between a geocentric mind-set and multinational strategy? Journal of International Business Studies, 25(3), 493-511.

Krippendorff, K. (1980). Content analysis: An introduction to its methodology. Beverly Hills, CA: SAGE Publications.

Krippendorff, K. (2004). Content analysis: An introduction to its methodology (2nd ed.). Thousand Oaks, CA: SAGE Publications.

Kuemmerle, W. (1997). Building effective R\&D capabilities abroad. Harvard Business Review, 75, 61-72. 
Lavie, D., Kang, J., \& Rosenkopf, L. (2011). Balance within and across domains: The performance implications of exploration and exploitation in alliances. Organization Science, 22(6), 1517-1538.

Levy, O., Beechler, S., Taylor, S., \& Boyacigiller, N. A. (2007a). What we talk about when we talk about "global mindset:" Managerial cognition in multinational corporations. Journal of International Business Studies, $38(2), 231-258$.

Levy, O., Taylor, S., Boyacigiller, N. A., \& Beechler, S. (2007b). Global mindset: A review and proposed extensions. In M. Javidan, R. M. Steers, \& M. A. Hitt (Eds.), Advances in international management: The global mindset (pp. 11-47). Oxford, UK: Elsevier.

Liu, Y., Loh, H. T., \& Sun, A. (2009). Imbalanced text classification: A term weighting approach. Expert Systems with Applications, 36(1), 690-701.

Lubatkin, M., \& Shrieves, R. E. (1986). Towards reconciliation of market performance measures to strategic management research. Academy of Management Review, 11(3), 497-512.

Lyon, D. W., Lumpkin, G. T., \& Dess, G. G. (2000). Enhancing entrepreneurial orientation research: Operationalizing and measuring a key strategic decision making process. Journal of Management, 26(5), 1055-1085.

Manning, C. D. (2003). Probabilistic syntax. In R. Bod, J. Hay, \& S. Jannedy (Eds.), Probabilistic linguistics (pp. 289-341). Cambridge, MA: MIT Press.

Manning, C. D., \& Schütze, H. (1999). Foundations of statistical natural language processing (vol. 999. Cambridge, MA: MIT Press.

Messick, S. (1989). Meaning and values in test validation: The science and ethics of assessment. Educational Researcher, 18(2), 5-11.

Messick, S. (1995). Standards of validity and the validity of standards in performance assessment. Educational Measurement: Issues and Practice, 14(4), 5-8.

Morris, R. (1994). Computerized content analysis in management research: A demonstration of advantages \& limitations. Journal of Management, 20(4), 903-931.

Neuendorf, K. A. (2002). The content analysis guidebook. Thousand Oaks, CA: SAGE Publications.

Nguyen, B. D. (2015). Is more news good news? Media coverage of CEOs, firm value, and rent extraction. Quarterly Journal of Finance, 5(4), 1-38.

Nummela, N., Saarenketo, S., \& Puumalainen, K. (2004). A global mindset-a prerequisite for successful internationalization? Canadian Journal of Administrative Sciences/Revue Canadienne des Sciences de l'Administration, 2l(1), 51-64.

Nunnally, J. C., \& Bernstein, I. H. (1994). Psychometric theory (3rd ed.). New York, NY: McGraw-Hill.

Pennebaker, J. W., Mehl, M. R., \& Niederhoffer, K. G. (2003). Psychological aspects of natural language use: Our words, our selves. Annual Review of Psychology, 54(1), 547-577.
Perlmutter, H. V. (1969). The tortuous evolution of the multinational corporation. Columbia Journal of World Business, 4(1), 9-18.

Pollach, I. (2012). Taming textual data: The contribution of corpus linguistics to computer-aided text analysis. Organizational Research Methods, 15(2), 263-287.

Raman, R., Chadee, D., Roxas, B., \& Michailova, S. (2013). Effects of partnership quality, talent management, and global mindset on performance of offshore IT service providers in India. Journal of International Management, 19(4), 333-346.

Rhinesmith, S. H. (1992). Global mindsets for global managers. Training \& Development, 46(10), 63-69.

Rhinesmith, S. H. (1996). A manager's guide to globalization: Six skills for success in a changing world (2nd ed.). New York, NY: McGraw-Hill.

Salton, G., \& Buckley, C. (1988). Term-weighting approaches in automatic text retrieval. Information Processing \& Management, 24(5), 513-523.

Short, J. C., Broberg, J. C., Cogliser, C. C., \& Brigham, K. H. (2010). Construct validation using computer-aided text analysis (CATA) an illustration using entrepreneurial orientation. Organizational Research Methods, 13(2), 320-347.

Story, J. S., \& Barbuto Jr, J. E. (2011). Global mindset: A construct clarification and framework. Journal of Leadership \& Organizational Studies, 18(3), 377-384.

Tetlock, P. C. (2007). Giving content to investor sentiment: The role of media in the stock market. Journal of Finance, 62(3), 1139-1168.

Tetlock, P. C., Saar-Tsechansky, M., \& Macskassy, S. (2008). More than words: Quantifying language to measure firms' fundamentals. Journal of Finance, 63(3), 1437-1467.

Titus Jr., V., House, J. M., \& Covin, J. G. (2014). The influence of exploration on external corporate venturing activity. Journal of Management, 43(5), 1609-1630.

Uotila, J., Maula, M., Keil, T., \& Zahra, S. A. (2009). Exploration, exploitation, and financial performance: analysis of S\&P 500 corporations. Strategic Management Journal, 30(2), 221-231.

Vagnani, G. (2015). Exploration and long-run organizational performance: The moderating role of technological interdependence. Journal of Management, 41(6), 1651-1676.

Walrave, B., van Oorschot, K. E., \& Romme, A. G. L. (2011). Getting trapped in the suppression of exploration: A simulation model. Journal of Management Studies, 48(8), 1727-1751.

Weber, R. P. (1990). Basic content analysis. Newbury Park, CA: Sage.

Wolfe, M. T., \& Shepherd, D. A. (2015). "Bouncing back" from a loss: Entrepreneurial orientation, emotions, and failure narratives. Entrepreneurship Theory and Practice, 39(3), 675-700. 


\section{Appendix}

Table A1

Examples of Contexts of Deductive and Inductive Keywords

Keywords Maintained keywords: Examples of keywords used in Global Mind-set context

Deductive keywords

Multinational "The Cisco-powered network offers Digital Island's multinational customers reliable, secure, and high-performance global IP services."

Overseas "Toshiba will cut 8,500 jobs in Japan, equal to 5.6\% of its domestic group workforce, through attrition. But the company plans to increase its overseas workforce."

Worldwide "Alcatel, the worldwide leader in ADSL solutions, is providing ADSL equipment and technical support to help resolve interoperability challenges within the lab's multi-vendor testing environment."

Transnational "This represents the largest capital expenditure by BASF in Asia and the first steam cracker project in China by a foreign company, said the company, envisioning a "transnational enterprise."

Internationally "With our domestic infrastructure largely in place and momentum building internationally, we have renewed our focus on leveraging our expertise in inhaled antibiotics into a broader product offering, and more immediately."

Multicultur "Given the fact that the orders are coming in from different regions and cultures, ABB is also gaining from its dedication to understanding the multicultural nature of modern research and researchers."

Global "A lesson learned by the company in keeping up with its globalization is to be able to translate the company's value and still respect other cultures."

Crosscultur "Motorola's teams of engineers, technicians, and business managers has worked round-the-clock, 7 days a week, in cross-cultural environments with partners around the world."

Borderless "Based upon its vision of a future operating environment defined by ceaseless, development of innovative technologies, and intensifying borderless competition, Mitsubishi Chemical is developing increasingly high value-added."

Foreign "It is said that the company is talking about alliances with some foreign drug firms. Mitsubishi absorbed Tokyo Tanabe in order to strengthen marketing and research capability"

Inductive keywords

Countries "Toshiba India would promote operations in it and infrastructure segments, along with providing marketing and sales support to all Toshiba group products in neighboring countries, including Nepal and Sri Lanka."

Bilateral "Economics Minister Wang Chih-Kang was scheduled to conclude a strategic alliance agreement with Sweden's Ericsson Ltd. on Monday in hopes of promoting bilateral cooperation as well as enhancing Taiwan's industrial technology."

Offshore "The company said it would consider shifting production offshore because of the yen's recent gains against the U.S. dollar."

Keywords Dropped keywords: Examples of ambiguous or out-of-context occurrences

Deductive keywords

Complex

"From complex e-business transactions and simple business processes, Livelink delivers true dynamic collaboration between individuals, organizations, and large trading communities."

Conceptualization "The company will have transitioned from initial product conceptualization to product availability in less than 12 months, led by Bell Labs."

Context

"Entering into a cooperative research and development agreement (CRADA) to develop new applications for personal tokens within the context of small but powerful secure computing..."

Integrat

"Due to a compelling combination of fast throughput speeds, reasonable pricing, and integrated content..."

Novel

"We are excited at this opportunity to demonstrate novel applications of our innovative proteomics technologies in drug discovery with a top-tier pharmaceutical company."

Tolerant

"Balancing and fault-tolerant capabilities for multi-threaded applications running across multiple CPUs..."

Emerging "Our work represents the future of patient care, and we're committed to working with Sun to more fully utilize the emerging technologies." 
Table A1

Continued

\begin{tabular}{|c|c|}
\hline Keywords & ed keywords: Examples of ambiguous or out-of-context occurrences \\
\hline Divers & $\begin{array}{l}\text { "With its flagship family of combretastatin-based vascular targeting agents, Oxigene is } \\
\text { developing a diverse portfolio of innovative products to combat these conditions..." }\end{array}$ \\
\hline Cosmopolitan & $\begin{array}{l}\text { "In Silicon Valley, the birthplace of the high technology industry, the tech museum of innovation } \\
\text { is a cosmopolitan museum singularly focused on technology." }\end{array}$ \\
\hline Greenfield & “...modularized designs and adaptability to both retrofit and greenfield applications." \\
\hline Openness & $\begin{array}{l}\text { "As planned by this initiative, is based in the tradition of the Java technology's openness and } \\
\text { portability." }\end{array}$ \\
\hline Cultur & $\begin{array}{l}\text { "The redesigned typeface with the traditional Merck blue represents the basic principles and } \\
\text { unique culture of our company." }\end{array}$ \\
\hline Ambiguity & $\begin{array}{l}\text { "The major stumbling block in the last two deals was there was ambiguity about who was going } \\
\text { to be CEO." }\end{array}$ \\
\hline Responsiveness & $\begin{array}{l}\text { "...stability of a world leader in telecommunications along with the speedy responsiveness and } \\
\text { flexibility of a small, R\&D-focused entrepreneurial organization." }\end{array}$ \\
\hline Opportunit & $\begin{array}{l}\text { "...distribution channels for storage networking solutions, and customers would be well served to } \\
\text { investigate this opportunity." }\end{array}$ \\
\hline Ethnic & $\begin{array}{l}\text { "...underweight, normal weight, overweight, or obese, by entering age, gender, and ethnicity; } \\
\text { obtain information on current health risk factors based on their profile..." }\end{array}$ \\
\hline \multicolumn{2}{|c|}{ Inductive keywords" } \\
\hline Expansion & "The investments we have made in capacity expansion and the development of new products..." \\
\hline Subsidiary & "Before TSC becomes a 100\% Motorola subsidiary, we've started preparations..." \\
\hline Venture & "Investment bankers and venture capital people that we talk to, they' re not even questioning that." \\
\hline
\end{tabular}

Note. Grammar and spelling mistakes were part of the original text.

Table A2

Predictive Validity Results for Alternative Article Categorization Rules

\begin{tabular}{llll}
\hline & Minimum 2 keywords/article & Minimum 1 keyword/article & Minimum 3 keywords/article \\
\hline Global Mind-set & $0.1296^{* *}$ & $0.1253^{* *}$ & $0.1230^{*}$ \\
& $(0.0586)$ & $(0.0491)$ & $(0.0701)$ \\
N observations & 876 & 876 & 876 \\
N Firm & 145 & 145 & 145 \\
Adjusted R & 0.82 & 0.82 & 0.82 \\
F-test & 469.96 & 469.94 & 478.42
\end{tabular}

Note. All models use the same coverage rule of minimum five articles per firm per year and include the full set of control variables. Standard errors in parentheses.

${ }^{*} p<.1,{ }^{* * *} p<.05,{ }^{* * *} p<.01$. 